\title{
Controls on barium and radium-226 distributions along GEOTRACES GP15
}

\author{
EMILIE LE ROY ${ }^{1}$, MATTHEW A CHARETTE ${ }^{1}$, PAUL B \\ HENDERSON $^{1}$, ALAN SHILLER ${ }^{2}$, WILLARD MOORE ${ }^{3}$, \\ RIAN LAWRENCE ${ }^{4}$, AVANTI SHRIKUMAR ${ }^{4}$, KAREN \\ LYNN CASCIOTTI $^{4}$, PIETER VAN BEEK ${ }^{5}$, MARC \\ SOUHAUT $^{5}$, MAUREEN AURO ${ }^{1}$ AND TRISTAN J \\ HORNER $^{1}$
}

${ }^{1}$ Woods Hole Oceanographic Institution

${ }^{2}$ University of Southern Mississippi

${ }^{3}$ University of South Carolina

${ }^{4}$ Stanford University

${ }^{5}$ Laboratoire d'Etudes en Géophysique et Océanographie

Spatiales

Presenting Author: eleroy@whoi.edu

Radium-226 $\left({ }^{226} \mathrm{Ra} ; \mathrm{t}_{1 / 2}=1,602 \mathrm{yr}\right)$ and $\mathrm{Ba}$ are strongly correlated to one another in the ocean. However, the extent to which this correlation reflects an active biogeochemical coupling versus a passive sharing of the same circulation is unclear. The GEOTRACES GP15 section provides an ideal dataset with which to test these hypotheses. Radium-226 activities and $\mathrm{Ba}$ concentrations were determined in the Pacific along $152^{\circ} \mathrm{W}$ from $55^{\circ} \mathrm{N}$ to $20^{\circ} \mathrm{S}$ on samples collected between SeptemberNovember 2018. We isolated the circulation component of the distribution by performing an optimum multiparameter analysis of the encountered water masses and modeled the distributions of ${ }^{226} \mathrm{Ra}$ and $\mathrm{Ba}$ based solely on physical transport of these water masses. The difference between the modeled and observed ${ }^{226} \mathrm{Ra}$ and $\mathrm{Ba}$ distributions reflects three significant non-conservative processes that influence ${ }^{226} \mathrm{Ra}$ and $\mathrm{Ba}$ distributions in the Pacific. First, in the north Pacific, intermediate waters $(0-1,500 \mathrm{~m})$ exhibit substantial deficits in ${ }^{226} \mathrm{Ra}$ and $\mathrm{Ba}$ that are likely caused by their incorporation into barite. Second, significant positive ${ }^{226} \mathrm{Ra}$ and $\mathrm{Ba}$ anomalies are found in deep waters (below 3,000 $\mathrm{m})$ along the entire GP15 section, reflecting accumulation of ${ }^{226} \mathrm{Ra}$ and $\mathrm{Ba}$ from sediment diffusion and particle dissolution, respectively. Third, there are persistent positive ${ }^{226} \mathrm{Ra}$ anomalies between $5^{\circ} \mathrm{N}$ and $20^{\circ} \mathrm{S}$ around $2,500 \mathrm{~m}$. Importantly, there are no corresponding $\mathrm{Ba}$ anomalies, suggesting a solute source unique to ${ }^{226} \mathrm{Ra}$, such as from hydrothermalism. We augmented this statistical analysis with measurement of particulate ${ }^{226} \mathrm{Ra}$, Ba, and $\mathrm{Ba}$ isotopes, which bring additional insight into the sources of particulate material to the deep ocean. 